a small tuft of white hairs. There is a darker green line down the centre of the back, and the colour of the body becomes a little paler between the segments or rings. The under side is somewhat darker in colour than the upper, witl a few whitish hairs. It becomes full grown about the middle of June, and then changes to a chrysali.

The chrysalis, fig. $15, b$, is a very odd looking thing, nearly hal? an inch long; angular and rugged in outline. It wriggles and trist, abont very briskly when touched. At first it is of a pale yellowish green colour, which gradually changes to a reddish brown. We have often found them attached to the under side of the leaves.

In less than a fortnight the noth, $d$, fig. 15, makes its appearance. It is an elegant little creature; its wings are very delicately construcled and measure, when expanded, about seven-tenths of an inch. The fore wings are long and narrow and cleft down the middle about half way to their base, the posterior half of the wing having a notch in: the outer margin. They are of a yellowish brown colour and metallic iustre, with several dull whitish streaks and spots. The hind wings are divided into three lobes; the lower division is complete, extending to the base, while the upper one is only about two-thirds as deep; their colour is yellowish brown also, with the same burnished metallic appearance, and with a streak of dull white on the hinder lobe. The outer and hind margins of the wings, as well as all the edges of theit lobes, are beatufully bordered with a deep whitish fringe, sprinkled with brown. The body of the moth is long and slender, and of $a$ iittle darker colour than the wings; the legs are also long, banded alternately with yellowish brown and white, and powdered with metalli. scales. The unnatural grouping of the leaves when fastened together to form the home of this insect while in the larval state, leads to it: ready detection, when it may be easily crushed with the hand. It $i$ : very generally distributed throughout the provinces of Ontario and Quebec.

\title{
ADVERTISEMENTS
}

ExCHANGF.-I am desirous to exchange English for Canadian or American Lepidoptera. I. C. WASsiziman, Beverly Terrace, Cullercoats, North Shields, England.

COLFOPTI:RA FOR SALF-A number of Rocky Mountain Coleop. tera will soon be for sale in sets by JoHn Aminurst, 19, Prospect Street, Brooklyn, N. Y.

\section{TO CORRESPONDEN'TS}

J. C. Wassirmañ-Plusia balluca is very like P. chrysitis. We know the latter insect well. 